\title{
PERBANDINGAN DAYA DUKUNG AKSIAL , EFISIENSI, BIAYA FONDASI TIANG PANCANG DAN TIANG BOR UNTUK RUSUNAWA DAAN MOGOT
}

\author{
Stefanus Andy Kurniawan' ${ }^{1}$ \& Gregorius Sandjaja² \\ ${ }^{1}$ Program Studi Sarjana Teknik Sipil, Universitas Tarumanagara, Jl. Letjen S. Parman No.1 Jakarta \\ Stefanusandy1998@gmail.com \\ ${ }^{2}$ Program Studi Sarjana Teknik Sipil, Universitas Tarumanagara, Jl. Letjen S. Parman No.1 Jakarta \\ gregoriuss@ft.untar.ac.id
}

Masuk: 06-01-2021, revisi: 13-01-2021, diterima untuk diterbitkan: 11-02-2021

\begin{abstract}
The location itself was already planed with bored pile $\phi 100 \mathrm{~cm}$ with $40 \mathrm{~m}$ depth and it cost Rp.10.658.080,00 (with tax 10\%). The purpose of this research to make an alternative with Driven Pile to see who more efficient from these two foundation, and got an alternative to use driven pile with $\phi 50 \mathrm{~cm}$ dimension with $36 \mathrm{~m}$ depth that just need cost Rp.5.945.005.364,00 (with tax 10\%) with 44,2\% cost efficiency
\end{abstract}

Keywords: Foundation, Driven Pile, Bore Pile, Price, Comparison, Efficiency

\section{ABSTRAK}

Pada lokasi ini sendiri fondasi dalam sudah direncanakan dengan menggunakan tiang bor dengan diameter $\phi 100$ cm serta kedalaman 40 m memakan biaya sebesar Rp. 10.658.080.000,00 (dengan PPN 10\%). Lalu pada studi ini ditujukkan untuk melakukan alternatif menggunakan tiang pancang untuk melihat mana yang lebih efisien dari kedua fondasi tersebut, dan didapatkan alternatif dengan diameter tiang pancang $\phi 50 \mathrm{~cm}$ dengan Panjang $36 \mathrm{~m}$ membutuhkan biaya sebesar Rp.5.945.005.364,00 (dengan PPN 10\%) dengan perbandingan efisiensi biaya sebesar $44,22 \%$.

Kata kunci: Fondasi, Tiang Pancang, Tiang Bor, Harga, Perbandingan, Efisiensi

\section{PENDAHULUAN}

Pada Bangunan Rusunawa Daan Mogot sudah menggunakan fondasi dalam tiang bor dengan diameter $\phi 100 \mathrm{~cm}$ dengan kedalaman $40 \mathrm{~m}$. Pada studi ini akan dilakukan perbandingan penghematan biaya dengan menggunakan tiang pancang berdiameter $\$ 50 \mathrm{~cm}$ dengan kedalaman $36 \mathrm{~m} \& 40 \mathrm{~m}$. Lalu dicek untuk memenuhi daya dukung dan penurunan, lalu dibandingkan harganya dan dilihat mana yang lebih efisien.

\section{METODE PENELITIAN}

Daya dukung fondasi menggunakan daya dukung ujung tiang dan daya dukung selimut. Perhitungan ini berdasarkan teori sudah diuraikan dengan banyak pendekatan antara lain menggunakan data laboratorium dan lapangan menggunakan metode Meyerhoff, Meyerhoff (Uji SPT) dan L.Decourt.

Daya dukung fondasi menggunakan daya dukung ujung tiang dan daya dukung selimut. Perhitungan ini berdasarkan teori sudah diuraikan dengan banyak pendekatan antara lain menggunakan data laboratorium dan lapangan menggunakan metode Meyerhoff, Meyerhoff (Uji SPT) dan L.Decourt.

\section{Daya Dukung Aksial Tiang Tunggal}

Rumus daya daya dukung dapat diperoleh dari persamaan :

$$
\begin{array}{ll}
\mathrm{Qu} & =\mathrm{Qs}+\mathrm{Qp} \\
\mathrm{Qijin} & =\mathrm{Qu} / \mathrm{SF}
\end{array}
$$

Dengan $\mathrm{Qu}=$ Daya dukung ultimit, Qs = Daya Dukung selimut tiang, $\mathrm{Qp}=$ Daya Dukung Ujung , Qijin = Daya Dukung Ijin \& SF = Safety Factor (Faktor Keamanan) umumnya $2.5-4$ 


\section{Metode Meyerhoff}

Daya dukung ujung fondasi tiang pancang dinyatakan oleh rumus berikut :

$$
\text { Qall = Ap x qp }
$$

Dengan qp = tahanan ujung tiang per satuan luas (ton $\left./ \mathrm{m}^{\wedge} 2\right)$, Ap $=$ Luas Penampang tiang $\left(\mathrm{m}^{\wedge} 2\right)$

Tahanan untuk ujung tiang per satuan luas dapat didapat dengan :

a. Untuk Tanah Kohesif

$$
\mathrm{qp}=\mathrm{Nc} . \mathrm{Cu}
$$

Dimana Nc dianggap 9 karena sudut friksi geser dalam dianggap 0 karena rusak saat baru dipancang

b. Untuk Tanah non Kohesif

Untuk $\mathrm{N} \leq 60$ maka,

$$
\text { qp } \left.=\text { Nq. q' (ton } / \mathrm{m}^{\wedge} 2\right)<400
$$

Dengan $\mathrm{Nq}=$ Nilai rata - rata SPT \& q’ = Tegangan vertical efektif

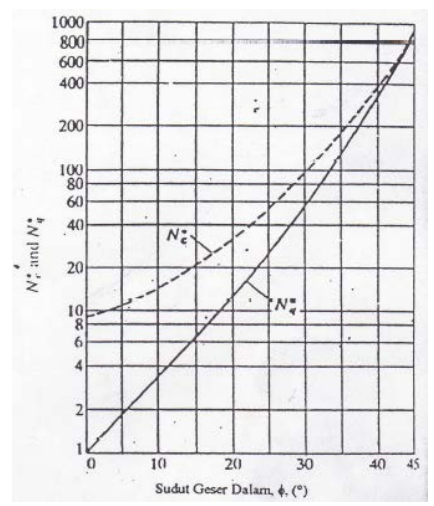

Gambar 1 Harga Nc \& Nq (Rahardjo, 2005)

Gambar 1 menunjukkan harga Nc\& Nq yang akan dipakai untuk menghitung daya dukung ujung tiang berdasarkan metode yang dibutuhkan.

Lalu untuk daya dukung selimut (skin Friction) :

$$
\mathrm{Qs}=\mathrm{f} \times \Delta \mathrm{L} \times \mathrm{p}
$$

Dengan, $\mathrm{F}=$ Tahanan satuan skin friction (ton $\left./ \mathrm{m}^{\wedge} 2\right), \Delta \mathrm{L}=$ Panjang Tiang yang diselimuti tanah $(\mathrm{m}) \& \mathrm{p}=$ Keliling Penampang Tiang

Untuk tahanan satuan skin friction (f) dapat diperoleh sebagai barikut :

a. Pada Tanah Kohesif (Meyerhoff) :

$$
\mathrm{f}=\alpha \cdot \mathrm{Cu}
$$

Dengan $\mathrm{f}=$ Gesekan selimut,$\alpha=$ Faktor adhesi $\& \mathrm{Cu}=$ Kohesi Tanah $\left(\right.$ ton $\left./ \mathrm{m}^{\wedge} 2\right)$

b. Pada Tanah non Kohesif

$$
\mathrm{f}=\mathrm{K} \cdot \sigma^{\prime} \delta\left(\operatorname{ton} / \mathrm{m}^{\wedge} 2\right)
$$

Dengan $\mathrm{K}=$ Konstanta, $\sigma^{\prime}=$ Tegangan Vertikal tanah $\& \delta=$ konstanta 
Tabel 1 Harga K \& $\delta$

\begin{tabular}{cccc}
\hline \multirow{2}{*}{ Bahan Tiang } & $\delta$ & \multicolumn{2}{c}{ Nilai K } \\
\cline { 3 - 4 } & & Kepadatan Relatif Tinggi $\quad$ Kepadatan Relatif Rendah \\
\hline Baja & $20^{\circ}$ & 0,5 & 1 \\
Beton & $\frac{3}{4} \phi$ & 1 & 2 \\
\hline
\end{tabular}

(Sumber : Reese, 1977)

Tabel 1 menunjukkan harga $\mathrm{K} \& \delta$, parameter tersebut digunakan untuk menghitung daya dukung ujung tiang dengan metode Meyerhoff dimana parameter ditentukan berdasarkan jenis bahan tiang yang digunakan.

\section{Metode Meyerhoff (Uji SPT)}

Daya Dukung ujung tiang dapat dihitung dengan persamaan Meyerhof (Rahardjo, 2005) :

$$
\mathrm{Qu}=40 . \mathrm{Nb} \cdot \mathrm{Ap}+0.2 \mathrm{~N} \cdot \mathrm{As}
$$

Dengan, $\mathrm{Nb}=$ Harga N-Spt pada elevasi dasar tiang, Ap = Luas Penampang Dasar Tiang \& $\mathrm{N}=$ Nilai rata - rata SPT pada selimut tiang

\section{Metode L. Decourt}

Daya Dukung ujung tiang dapat dihitung dengan persamaan L.Decourt (Rahardjo, 2005) :

$$
\mathrm{Qp}=\mathrm{Nb} . \mathrm{K} \cdot \mathrm{Ap}
$$

Dengan Nb = Harga N-SPT pada elevasi dasar tiang, Ap = Luas Penampang Dasar Tiang \& K = Koefisien K dari L. Decourt

Tabel 2 Harga K

\begin{tabular}{cc}
\hline Jenis Tanah & Nilai K (ton/m2) \\
\hline Lempung & 12 \\
Lanau Berlempung & 20 \\
Lanau Berpasir & 25 \\
Pasir dan Kerikil & 40 \\
\hline
\end{tabular}

(Sumber : Rahardjo, 2005)

Tabel 2 menunjukkan harga K untuk tiap jenis tanah, harga K digunakan di metode L.Decourt untuk menghitung daya dukung ujung tiang.

\section{Efisiensi Kelompok Tiang}

Jika pada satu titik terjadi pembebanan dan satu tiang tunggal tidak mampu menahan beban yang diterima maka akan ditambah tiang tunggal yang lainnya, namun tiang tersebut dianggap tidak bekerja 100\% untuk memikul beban, maka akan dihitung efisiensinya, Formula formula yang digunakan untuk menghitung efisiensi :

\section{Formula Converse Labare}

Formula berikut digunakan untuk menghitung efisiensi tiang berdasarkan jumlah tiang secara baris dan kolom, selain itu memperhatikan jarak dan ukuran tiang tersebut.

$$
\mathrm{Eg}=1-\left(\frac{(n-1) m+(m-1) n}{90 \cdot m \cdot n}\right) \theta
$$


Dengan $\theta=\operatorname{arc} \tan \left(\frac{d}{s}\right), \mathrm{m}=$ jumlah kolom, $\mathrm{d}=$ diameter tiang bor, $\mathrm{n}=$ jumlah baris, $\mathrm{s}=$ jarak antar tiang

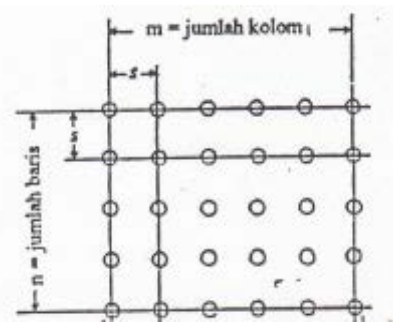

Gambar 2 Ilustrasi m,n (Sumber : Rahardjo,2005)

Gambar 2 menunjukkan ilustrasi $\mathrm{m}$ dan n, dimana masing masing m merupakan jumlah tiang terhadap kolom dan $\mathrm{n}$ jumlah tiang terhadap baris.

\section{Formula Feld}

Rumus ini digunakan dengan cara mengurangi kapasitas daya dukung setiap tiang terdekat dengan $\frac{1}{16}$ tanpa memperhatikan jarak, kelemahan dari feld ini adalah tidak memperhatikan jarak.

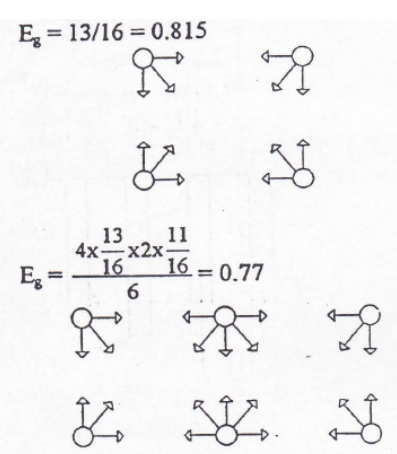

Gambar 3 Ilustrasi Penyebaran Gaya (Sumber : Rahardjo,2005)

Gambar 3 menunjukkan ilustrasi penyebaran gaya berdasarkan metode feld. Dimana masing masing tiang terdekat mengurangi kapasitas daya tiang sebesar $\frac{1}{16}$.

\section{Formula Los Angeles}

$$
\mathrm{Eg}=1-\frac{\mathrm{D}}{\pi \cdot \mathrm{s} \cdot \mathrm{m} \cdot \mathrm{n}}[\mathrm{m}(\mathrm{n}-1)+\mathrm{n}(\mathrm{n}-1)+(\mathrm{m}-1)(\mathrm{n}-1) \sqrt{2}]
$$

Dengan $\mathrm{m}=$ jumlah kolom, $\mathrm{n}=$ jumlah baris $\& \mathrm{~s}=$ jarak antar tiang

\section{Formula Seiler \& Keeney}

$$
E_{g}=\left[1-\frac{36 s(m+n-2)}{\left(75 s^{2}-7\right)(m+n-1)}\right]+\frac{0,3}{m+n}
$$

Dengan $\mathrm{m}=$ jumlah kolom, $\mathrm{n}=$ jumlah baris $\& \mathrm{~s}=$ jarak antar tiang

\section{Penurunan}

Pada dasarnya fondasi berdiri diatas tanah, sedangkan jenis tanah bermacam - macam, lalu fondasi yang bekerja di tanah lunak perlu dikaji ulang kemampuan daya dukung tiang dan besarnya penurunan yang terjadi. Selanjutnya apabila fondasi tersebut menghasilkan penurunan yang sangat besar, maka perlu adanya alternatif desain. Salah satu alternatifnya ialah fondasi rakit.

Penurunan fondasi tiang pada tanah kohesif terdiri dari 2 komponen yaitu :

- $\quad$ Penurunan seketika (short term settlement) yang segera terjadi setelah pembebanan bekerja

- Penurunan jangka panjang atau penurunan konsolidasi, yang terjadi secara berangsur angsur bersamaan dengan disipasi tekanan air pori ekses 
Penurunan fondasi tiang di tanah non kohesif hanya menghitung penurunan seketika.

\section{Penurunan Kelompok Tiang}

o Penurunan Segera

Penurunan segera atau penurunan elastis adalah penurunan akibat massa tanah yang tertekan dan terjadi segera setelah terjadi pembebanan dalam Hardiyatmo H.C. (2002) memberikan persamaan untuk penurunan segera adalah sebagai berikut :

$$
\mathrm{Si}=\mu_{1} \cdot \mu_{0} \cdot \frac{q \cdot B}{E}
$$

Dengan Si $=$ Penurunan Segera, $\mu 1=$ factor koreksi untuk lapisan tanah, $\mu 0=$ factor koreksi untuk kedalaman fondasi Df, q = tekanan fondasi netto, $\mathrm{B}=$ lebar fondasi \& E = Modulus Elastisitas tanah
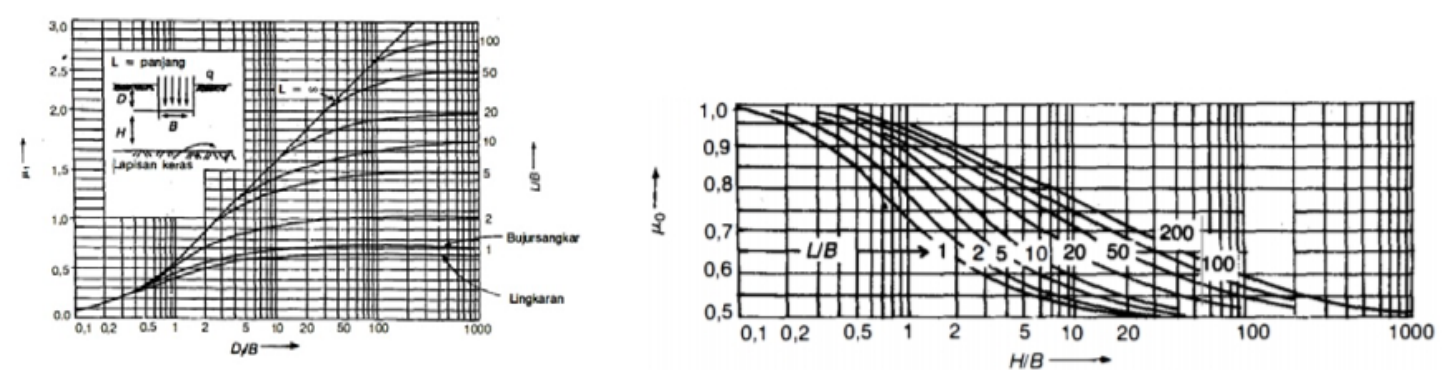

Gambar 4 Grafik untuk nilai $\mu 1$ dan $\mu 0$ (Rahardjo, 2005)

Gambar 4 menunjukkan nilai $\mu 1$ dan $\mu 0$ yang akan digunakan untuk menghitung penurunan segera, dimana masing masing $\mu 1$ dan $\mu 0$ merupakan factor koreksi untuk lapisan tanah dan kedalaman fondasi.

Nilai Modulus merupakan sifat - sifat elastis pada tanah yang penting karena umumnya dipakai untuk menghitung perkiraan - perkiraan penurunan fondasi. Nilai perkiraan modulus elastis tanah dapat ditentukan dengan melihat Tabel dibawah :

Tabel 3 Nilai Modulus (Es) untuk macam - macam jenis tanah (sumber : Bowles 1988)

\begin{tabular}{ccc}
\hline \multirow{2}{*}{ Tanah } & \multicolumn{2}{c}{ Ks } \\
\cline { 2 - 3 } & Lempung & Mpa \\
\hline Sangat Lunak & $50-250$ & $2-15$ \\
Lunak & $100-500$ & $5-25$ \\
Sedang & $300-1000$ & $15-50$ \\
Keras & $1000-2000$ & $50-100$ \\
Berpasir & $500-5000$ & $25-250$ \\
\hline
\end{tabular}

Tabel 3 diatas menunjukkan nilai modulus tanah, nilai Es ini digunakan untuk menghitung penurunan segera.

\section{Penurunan Kelompok Tiang pada tanah Lempung}

Perkiraan Penurunan fondasi tiang kelompok pada tanah lempung dapat menggunakan prosedur sebagai berikut :

Tentukan beban kerja :

$$
\mathrm{q}=\frac{Q}{B o \cdot L o}
$$

Beban kerja diatas dialihkan pada kedalaman 2/3 D di bawah pile cap. Penurunan tanah diatas kedalaman tersebut amat kecil dan dapat diabaikan

Beban Kerja disebarkan ke ebawah fondasi tiang dengan perkiraan pola penyebaram vertical : horizontal = $2: 1$ 
Tanah dibagi atas lapis - lapis dengan masing - masing lapis ditentukan parameter kompresibilitasnya, tegangan efektif awal (Po') dan besarnya beban luar $(\Delta \mathrm{P})$. Kemudian settlement tiap lapis dijumlahkan sebagai berikut :

$$
\mathrm{Sg}=\sum \frac{C c \cdot \Delta H}{1+e_{o}} \cdot\left(\frac{P o^{\prime}+\Delta P}{P o^{\prime}}\right)
$$

Jika tanah overkonsolidasi maka harus diperhitungkan dengan Cr ( rebound compression index) pada harga (Po’ + $\Delta \mathrm{P})<\mathrm{Pc}$ (Preconsolidation pressure) dan untuk $\left(\mathrm{Po}^{\prime}+\Delta \mathrm{P}\right)$ disesuaikan nilai penyebutnya.

$$
\mathrm{Sg}=\sum \frac{C r \cdot \Delta H}{1+e_{o}} \cdot \log \left(\frac{P c}{P o^{\prime}}\right)+\sum \frac{C r \cdot \Delta H}{1+e_{o}} \cdot \log \left(\frac{P o^{\prime}+\Delta \mathrm{P}}{P o^{\prime}}\right)
$$

\section{HASIL DAN PEMBAHASAN}

Rusunawa Daan Mogot direncanakan dengan jumlah 20 lantai untuk Gedung nya dengan denah lokasi kolom di bawah ini. Berat total Gedung ini sebesar 19668,59 ton dan distribusikan ke 32 kolom dan 2 shearwall. Kolom pada gedung tersebut menerima beban yang tidak sama. Lalu pada penelitian ini dicoba untuk mengganti tiang bor dengan alternatif tiang pancang.

\section{Lokasi Kolom Yang Ditinjau}

Kolom yang ditinjau ini dibagi menjadi 4 bagian yaitu Kolom Pojok, Kolom Tepi, Kolom Tengah B dan Kolom Tengah A, karena pile cap di tiap jenis kolom berbeda dan tiap kolom yang ditinjau dianggap menerima beban secara bersama.

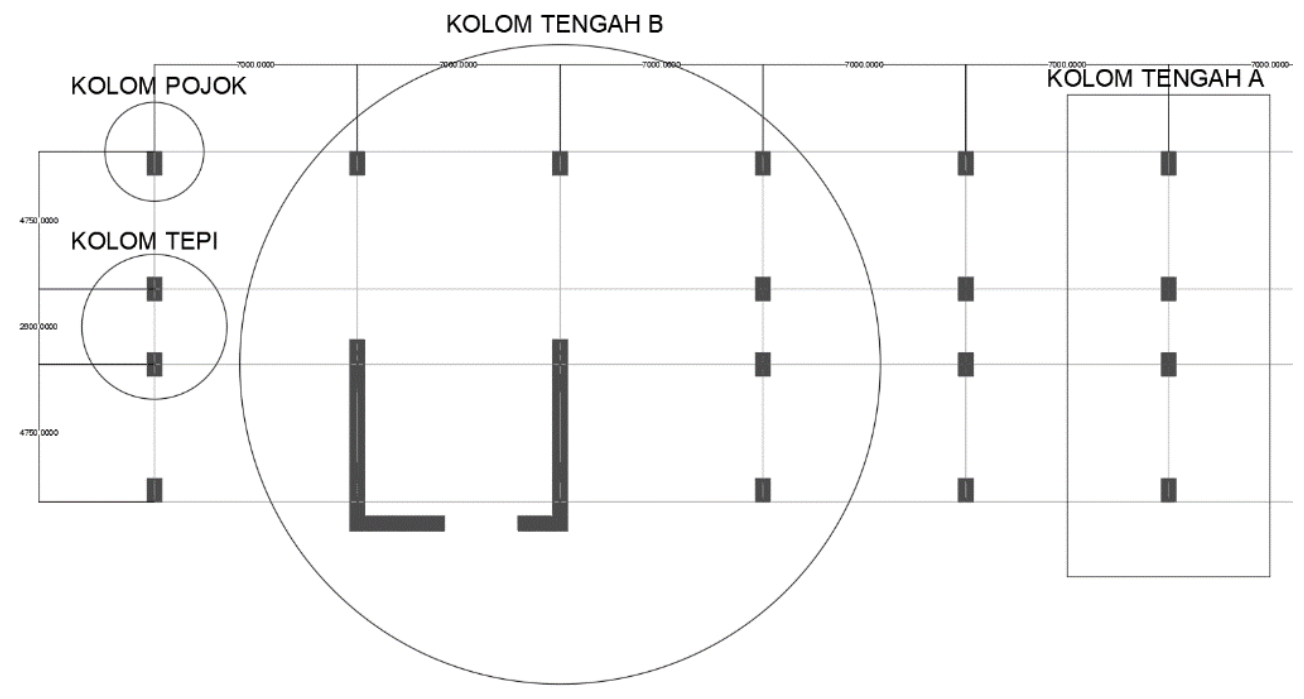

Gambar 5 Lokasi Kolom Yang Ditinjau

Gambar 5 menunjukkan tiap lokasi kolom yang ditinjau yang dibagi menjadi 4 bagian dan setiap bagian bekerja secara Bersama untuk menanggung beban diatas karena menjadi satu pile cap.

\section{Analisis daya dukung Tiang Tunggal}

Berikut merupakan perbandingan yang sudah dilakukan terhadap masing masing jenis tiang. 
Tabel 4 Daya Dukung Tiang Tunggal

\begin{tabular}{ccccc}
\hline Jenis tiang & Diameter $(\mathrm{m})$ & Kedalaman(m) & Metode & Daya Dukung (ton) \\
\hline Bor & 1 & 40 & Existing & 327,67 \\
Pancang & 0,5 & 40 & Meyerhoff & 187,6 \\
& & & Meyerhoff (SPT) & 157,12 \\
& & L.Decourt & 157,15 \\
Pancang & \multirow{2}{*}{36} & Aplikasi & 223,04 \\
& & Meyerhoff & 168,06 \\
& & Meyerhoff (SPT) & 149,464 \\
& & L.Decourt & 141,6925 \\
& & Aplikasi & 196,5 \\
\hline
\end{tabular}

Tabel 4 menunjukkan perbandingan daya dukung yang didapatkan dengan perbedaan metode masing masing jenis tiang dan kedalamannya

\section{Perbandingan Daya Dukung Terhadap Beban}

Tabel-tabeldibawah ini ditunjukkan untuk melihat perbandingan jumlah dan daya dukung tiang terhadap bebannya dan diambil yang mana yang paling efisien.

o Kolom Pojok

Tabel 5 menunjukkan konfigurasi fondasi tiang yang digunakan dengan membandingkan daya dukung terhadap beban yang diterima di kolom Pojok.

Tabel 5 Perbandingan Daya Dukung Terhadap Beban di Kolom Pojok

\begin{tabular}{|c|c|c|c|c|c|c|c|c|}
\hline $\begin{array}{l}\text { Jenis } \\
\text { Tiang }\end{array}$ & Diameter & $\begin{array}{c}\text { Kedalaman } \\
\text { (m) }\end{array}$ & Metode & $\begin{array}{c}\text { Daya } \\
\text { Dukung }\end{array}$ & $\begin{array}{c}\text { Jumlah } \\
\text { Tiang }\end{array}$ & Efisiensi & $\begin{array}{l}\text { T. Daya } \\
\text { Dukung }\end{array}$ & Beban \\
\hline Bor & 1 & 40 & Existing & 327,6 & 2 & - & 588,16 & 236,63 \\
\hline \multirow[t]{4}{*}{ Pancang } & 0,5 & 40 & Meyerhoff & 187,6 & 2 & 0,8975 & 336,75 & 236,63 \\
\hline & & & $\begin{array}{c}\text { Meyerhoff } \\
\text { (Uji SPT) }\end{array}$ & 157,12 & 2 & 0,8975 & 282,03 & 236,63 \\
\hline & & & L.Decourt & 157,15 & 2 & 0,8975 & 282,09 & 236,63 \\
\hline & & & Aplikasi & 223,4 & 2 & 0,8975 & 401 & 236,63 \\
\hline \multirow[t]{4}{*}{ Pancang } & 0,5 & 36 & Meyerhoff & 168,07 & 2 & 0,8975 & 301,68 & 236,63 \\
\hline & & & $\begin{array}{c}\text { Meyerhoff } \\
\text { (Uji SPT) }\end{array}$ & 149,46 & 2 & 0,8975 & 268,29 & 236,63 \\
\hline & & & L.Decourt & 141,69 & 2 & 0,8975 & 254,34 & 236,63 \\
\hline & & & Aplikasi & 196,5 & 2 & 0,8975 & 352,72 & 236,63 \\
\hline
\end{tabular}

o Kolom Tepi

Tabel 6 menunjukkan konfigurasi fondasi tiang yang digunakan dengan membandingkan daya dukung terhadap beban yang diterima di kolom Tepi. 
Tabel 6 Perbandingan Daya Dukung Terhadap Beban di Kolom Tepi

\begin{tabular}{|c|c|c|c|c|c|c|c|c|}
\hline $\begin{array}{l}\text { Jenis } \\
\text { Tiang }\end{array}$ & Diameter & $\begin{array}{c}\text { Kedalaman } \\
\text { (m) }\end{array}$ & Metode & $\begin{array}{c}\text { Daya } \\
\text { Dukung }\end{array}$ & $\begin{array}{c}\text { Jumlah } \\
\text { Tiang }\end{array}$ & Efisiensi & $\begin{array}{l}\text { T. Daya } \\
\text { Dukung }\end{array}$ & $\begin{array}{c}\text { Beban } \\
\text { (ton) }\end{array}$ \\
\hline Bor & 1 & 40 & Existing & 327,6 & 4 & - & 1064,92 & 679,73 \\
\hline \multirow[t]{4}{*}{ Pancang } & 0,5 & 40 & Meyerhoff & 187,6 & 6 & 0,79 & 889,24 & 679,73 \\
\hline & & & $\begin{array}{c}\text { Meyerhoff } \\
\text { (Uji SPT) }\end{array}$ & 157,12 & 6 & 0,79 & 744,75 & 679,73 \\
\hline & & & L.Decourt & 157,15 & 6 & 0,79 & 744,9 & 679,73 \\
\hline & & & Aplikasi & 223,4 & 4 & 0,8125 & 726,05 & 679,73 \\
\hline \multirow[t]{4}{*}{ Pancang } & 0,5 & 36 & Meyerhoff & 168,07 & 6 & 0,79 & 796,63 & 679,73 \\
\hline & & & $\begin{array}{c}\text { Meyerhoff } \\
\text { (Uji SPT) }\end{array}$ & 149,46 & 6 & 0,79 & 708,46 & 679,73 \\
\hline & & & L.Decourt & 141,69 & 8 & 0,78125 & 885,58 & 679,73 \\
\hline & & & Aplikasi & 196,5 & 5 & 0,8 & 786 & 679,73 \\
\hline
\end{tabular}

o Kolom Tengah A

Tabel 7 menunjukkan konfigurasi fondasi tiang yang digunakan dengan membandingkan daya dukung terhadap beban yang diterima di kolom Tengah A.

Tabel 7 Perbandingan Daya Dukung Terhadap Beban di Kolom Tengah A

\begin{tabular}{|c|c|c|c|c|c|c|c|c|}
\hline $\begin{array}{l}\text { Jenis } \\
\text { Tiang }\end{array}$ & Diameter & $\begin{array}{c}\text { Kedalaman } \\
\text { (m) }\end{array}$ & Metode & $\begin{array}{c}\text { Daya } \\
\text { Dukung }\end{array}$ & $\begin{array}{c}\text { Jumlah } \\
\text { Tiang }\end{array}$ & Efisiensi & $\begin{array}{l}\text { T. Daya } \\
\text { Dukung }\end{array}$ & $\begin{array}{c}\text { Beban } \\
\text { (ton) }\end{array}$ \\
\hline Bor & 1 & 40 & Existing & 327,6 & 10 & - & 3276,67 & 1766,9 \\
\hline \multirow[t]{4}{*}{ Pancang } & 0,5 & 40 & Meyerhoff & 187,6 & 14 & 0,723 & 1898,93 & 1766,9 \\
\hline & & & $\begin{array}{c}\text { Meyerhoff } \\
\text { (Uji SPT) }\end{array}$ & 157,12 & 16 & 0,72 & 1810,03 & 1766,9 \\
\hline & & & L.Decourt & 157,15 & 16 & 0,72 & 1810,38 & 1766,9 \\
\hline & & & Aplikasi & 223,4 & 14 & 0,723 & 2261,25 & 1766,9 \\
\hline \multirow[t]{4}{*}{ Pancang } & 0,5 & 36 & Meyerhoff & 168,07 & 16 & 0,72 & 1936,12 & 1766,9 \\
\hline & & & $\begin{array}{c}\text { Meyerhoff } \\
\text { (Uji SPT) }\end{array}$ & 149,46 & 20 & 0,7625 & 2279,33 & 1766,9 \\
\hline & & & L.Decourt & 141,69 & 20 & 0,7625 & 2160,81 & 1766,9 \\
\hline & & & Aplikasi & 196,5 & 14 & 0,723 & 1988,97 & 1766,9 \\
\hline
\end{tabular}

o Kolom Tengah B

Tabel 8 menunjukkan konfigurasi fondasi tiang yang digunakan dengan membandingkan daya dukung terhadap beban yang diterima di kolom Tengah B. 
Tabel 8 Perbandingan Daya Dukung Terhadap Beban di Kolom Tengah B

\begin{tabular}{|c|c|c|c|c|c|c|c|c|}
\hline $\begin{array}{l}\text { Jenis } \\
\text { Tiang }\end{array}$ & Diameter & $\begin{array}{c}\text { Kedalaman } \\
\text { (m) }\end{array}$ & Metode & $\begin{array}{c}\text { Daya } \\
\text { Dukung }\end{array}$ & $\begin{array}{c}\text { Jumlah } \\
\text { Tiang }\end{array}$ & Efisiensi & $\begin{array}{l}\text { T. Daya } \\
\text { Dukung }\end{array}$ & $\begin{array}{c}\text { Beban } \\
\text { (ton) }\end{array}$ \\
\hline Bor & 1 & 40 & Existing & 327,6 & 35 & - & 11468,3 & 6030,8 \\
\hline \multirow[t]{4}{*}{ Pancang } & 0,5 & 40 & Meyerhoff & 187,6 & 60 & 0,604 & 6798,77 & 6030,8 \\
\hline & & & $\begin{array}{c}\text { Meyerhoff } \\
\text { (Uji SPT) }\end{array}$ & 157,12 & 70 & 0,6 & 6599,07 & 6030,8 \\
\hline & & & L.Decourt & 157,15 & 70 & 0,6 & 6600,34 & 6030,8 \\
\hline & & & Aplikasi & 223,4 & 46 & 0,66 & 6782,42 & 6030,8 \\
\hline \multirow[t]{4}{*}{ Pancang } & 0,5 & 36 & Meyerhoff & 168,07 & 60 & 0,604 & 6090,7 & 6030,8 \\
\hline & & & $\begin{array}{c}\text { Meyerhoff } \\
\text { (Uji SPT) }\end{array}$ & 149,46 & 70 & 0,6 & 6277,49 & 6030,8 \\
\hline & & & L.Decourt & 141,69 & 72 & 0,599 & 6110,91 & 6030,8 \\
\hline & & & Aplikasi & 196,5 & 50 & 0,63 & 6189,75 & 6030,8 \\
\hline
\end{tabular}

Dari perhitungan daya dukung diatas, jika kita ingin memakai angka yang aman setiap tiang kita asumsikan memikul daya dukung terendah dari perhitungan diatas, jadi diambil L.Decourt untuk kasus ini.

\section{Perbandingan Settlement Tiap Kolom}

o Kolom Pojok

Tabel 10 menunjukkan penurunan total di kolom pojok dengan jenis kedalaman yang berbeda dimana masing masing didapatkan sebesar $1,485 \mathrm{~cm}$ dan $1,49 \mathrm{~cm}$

Tabel 9 Penurunan Tiang Di Kolom Pojok

\begin{tabular}{ccccc}
\hline Jenis Tiang & Diameter $(\mathrm{m})$ & Kedalaman $(\mathrm{m})$ & Jumlah Tiang & Penurunan $(\mathrm{cm})$ \\
\hline Pancang & 0,5 & 40 & 2 & 1,485 \\
Pancang & 0,5 & 36 & 2 & 1,49 \\
\hline
\end{tabular}

o Kolom Tepi

Tabel 11 menunjukkan penurunan total di kolom tepi dengan jenis kedalaman dan banyaknya tiang yang digunakan berbeda . Penurunan maksimal harus dicek terhadap penurunan ijin yaitu sebesar $15 \mathrm{~cm}$ + b/600 dimana b merupakan lebar pile cap (dalam cm)

Tabel 10 Penurunan Tiang Di Kolom Tepi

\begin{tabular}{ccccc}
\hline Jenis Tiang & Diameter $(\mathrm{m})$ & Kedalaman $(\mathrm{m})$ & Jumlah Tiang & Penurunan $(\mathrm{cm})$ \\
\hline Pancang & 0,5 & 40 & 4 & 3,06 \\
& & & 6 & 2,35 \\
Pancang & 0,5 & 36 & 5 & 3,71 \\
& & & 6 & 3,16 \\
& & 8 & 3,16 \\
\hline
\end{tabular}


o Kolom Tengah A

Tabel 12 menunjukkan penurunan total di kolom tengah A dengan jenis kedalaman dan banyaknya tiang yang digunakan berbeda . Penurunan maksimal harus dicek terhadap penurunan ijin yaitu sebesar $15 \mathrm{~cm}+\mathrm{b} / 600$ dimana b merupakan lebar pile cap (dalam $\mathrm{cm}$ )

Tabel 11 Penurunan Tiang Di Kolom Tengah A

\begin{tabular}{ccccc}
\hline Jenis Tiang & Diameter $(\mathrm{m})$ & Kedalaman $(\mathrm{m})$ & Jumlah Tiang & Penurunan (cm) \\
\hline Pancang & 0,5 & 40 & 14 & 5,4 \\
& & & 16 & 5,4 \\
Pancang & 0,5 & 36 & 14 & 6,23 \\
& & & 16 & 6,23 \\
& & 20 & 6,23 \\
\hline
\end{tabular}

o Kolom Tengah B

Tabel 13 menunjukkan penurunan total di kolom tengah B dengan jenis kedalaman dan banyaknya tiang yang digunakan berbeda. Penurunan maksimal harus dicek terhadap penurunan ijin yaitu sebesar $15 \mathrm{~cm}$ + b/600 dimana b merupakan lebar pile cap (dalam cm)

Tabel 12 Penurunan Tiang di Kolom Tengah B

\begin{tabular}{ccccc}
\hline Jenis Tiang & Diameter $(\mathrm{m})$ & Kedalaman $(\mathrm{m})$ & Jumlah Tiang & Penurunan $(\mathrm{cm})$ \\
\hline Pancang & 0,5 & 40 & 46 & 14,69 \\
& & & 60 & 14,69 \\
& & & 70 & 14,69 \\
Pancang & 0,5 & 36 & 50 & 15,29 \\
& & & 60 & 15,29 \\
& & 70 & 15,29 \\
& & 72 & 15,29 \\
\hline
\end{tabular}

\section{Perbandingan Jumlah dan Harga Tiang}

o Kolom Pojok

Tabel 14 menunjukkan perbandingan harga tiang dari tiap metode, jenis dan kedalaman yang berbeda untuk di kolom pojok dapat dipilih untuk tingkat keamanan tertinggi yaitu L. Decourt dengan kedalaman $36 \mathrm{~m}$ dengan efisiensi penghematan sebesar 68,3\%. 
Tabel 13 Perbandingan Jumlah dan Harga Tiang Kolom Pojok

\begin{tabular}{|c|c|c|c|c|c|c|}
\hline $\begin{array}{l}\text { Jenis } \\
\text { Tiang }\end{array}$ & Diameter & $\begin{array}{c}\text { Kedalaman } \\
\text { (m) }\end{array}$ & Metode & $\begin{array}{l}\text { Jumlah } \\
\text { Tiang }\end{array}$ & Harga & $\begin{array}{c}\% \\
\text { Penghematan }\end{array}$ \\
\hline Bor & 1 & 40 & Existing & 2 & Rp.183.760.000 & 100 \\
\hline \multirow[t]{4}{*}{ Pancang } & 0,5 & 40 & Meyerhoff & 2 & Rp.64.562.666 & 64,8 \\
\hline & & & $\begin{array}{l}\text { Meyerhoff } \\
\text { (Uji SPT) }\end{array}$ & 2 & Rp.64.562.666 & 64,8 \\
\hline & & & L.Decourt & 2 & Rp.64.562.666 & 64,8 \\
\hline & & & Aplikasi & 2 & Rp.64.562.666 & 64,8 \\
\hline \multirow[t]{4}{*}{ Pancang } & 0,5 & 36 & Meyerhoff & 2 & Rp.58.106.400 & 68,3 \\
\hline & & & $\begin{array}{l}\text { Meyerhoff } \\
\text { (Uji SPT) }\end{array}$ & 2 & Rp.58.106.400 & 68,3 \\
\hline & & & L.Decourt & 2 & Rp.58.106.400 & 68,3 \\
\hline & & & Aplikasi & 2 & Rp.58.106.400 & 68,3 \\
\hline
\end{tabular}

o Kolom Tepi

Dari kedua jenis kolom di tabel 15 dengan melihat aspek keamanan seperti penurunan dan kuat daya dukung diambil metode L. Decourt, untuk Kolom Pojok diambil 2 tiang dengan persentase efisiensi biaya sebesar 68,3\%, dan untuk kolom tepi menggunakan 8 tiang dengan persentase penghematan sebesar $36,7 \%$

Tabel 14 Perbandingan Jumlah dan Harga Tiang di Kolom Tepi

\begin{tabular}{|c|c|c|c|c|c|c|}
\hline $\begin{array}{l}\text { Jenis } \\
\text { Tiang }\end{array}$ & Diameter & $\begin{array}{l}\text { Kedalaman } \\
\text { (m) }\end{array}$ & Metode & $\begin{array}{c}\text { Jumlah } \\
\text { Tiang }\end{array}$ & Harga & $\begin{array}{c}\% \\
\text { Penghematan }\end{array}$ \\
\hline Bor & 1 & 40 & Existing & 4 & Rp.367.520.000 & 100 \\
\hline \multirow[t]{4}{*}{ Pancang } & 0,5 & 40 & Meyerhoff & 6 & Rp.193.687.998 & 47 \\
\hline & & & $\begin{array}{c}\text { Meyerhoff } \\
\text { (Uji SPT) }\end{array}$ & 6 & Rp.193.687.998 & 47 \\
\hline & & & L.Decourt & 6 & Rp.193.687.998 & 47 \\
\hline & & & Aplikasi & 4 & Rp.129.125.332 & 64,8 \\
\hline \multirow[t]{4}{*}{ Pancang } & 0,5 & 36 & Meyerhoff & 6 & Rp.174.319.200 & 52,5 \\
\hline & & & $\begin{array}{c}\text { Meyerhoff } \\
\text { (Uji SPT) }\end{array}$ & 6 & Rp.174.319.200 & 52,5 \\
\hline & & & L.Decourt & 8 & Rp.232.425.600 & 36,7 \\
\hline & & & Aplikasi & 5 & Rp.145.266.000 & 60,4 \\
\hline
\end{tabular}

o Kolom Tengah A

Tabel 16 menunjukkan perbandingan harga tiang dari tiap metode, jenis dan kedalaman yang berbeda untuk di kolom tengah A dapat dipilih untuk tingkat keamanan tertinggi yaitu L. Decourt dengan kedalaman $36 \mathrm{~m}$ dengan efisiensi penghematan sebesar 36,7\%. 
Tabel 15 Perbandingan Jumlah \& Harga Tiang di Kolom Tengah A

\begin{tabular}{|c|c|c|c|c|c|c|}
\hline $\begin{array}{l}\text { Jenis } \\
\text { Tiang }\end{array}$ & Diameter & $\begin{array}{c}\text { Kedalaman } \\
\text { (m) }\end{array}$ & Metode & $\begin{array}{c}\text { Jumlah } \\
\text { Tiang }\end{array}$ & Harga & $\begin{array}{c}\% \% \\
\text { Penghematan }\end{array}$ \\
\hline Bor & 1 & 40 & Existing & 10 & Rp.918.800.000 & 100 \\
\hline \multirow[t]{4}{*}{ Pancang } & 0,5 & 40 & Meyerhoff & 14 & Rp.451.938.662 & 50,8 \\
\hline & & & $\begin{array}{c}\text { Meyerhoff } \\
\text { (Uji SPT) }\end{array}$ & 16 & Rp.516.501.328 & 43,7 \\
\hline & & & L.Decourt & 16 & Rp.516.501.328 & 43,7 \\
\hline & & & Aplikasi & 14 & Rp.451.938.662 & 50,8 \\
\hline \multirow[t]{4}{*}{ Pancang } & 0,5 & 36 & Meyerhoff & 16 & Rp.464.851.200 & 49,4 \\
\hline & & & $\begin{array}{c}\text { Meyerhoff } \\
\text { (Uji SPT) }\end{array}$ & 20 & Rp.581.064.000 & 36,7 \\
\hline & & & L.Decourt & 20 & Rp.581.064.000 & 36,7 \\
\hline & & & Aplikasi & 14 & Rp.406.744.800 & 55,7 \\
\hline
\end{tabular}

o Kolom Tengah B

Dari kedua jenis kolom di tabel 17 dengan melihat aspek keamanan seperti penurunan dan kuat daya dukung diambil metode L. Decourt, untuk Kolom Tengah A diambil 20 tiang dengan persentase efisiensi biaya sebesar 36,7\%, dan untuk kolom tengah B menggunakan 72 tiang dengan persentase penghematan sebesar $34,9 \%$

Tabel 16 Perbandingan Jumlah Harga Tiang di Kolom Tengah B

\begin{tabular}{|c|c|c|c|c|c|c|}
\hline $\begin{array}{l}\text { Jenis } \\
\text { Tiang }\end{array}$ & Diameter & $\begin{array}{l}\text { Kedalaman } \\
\text { (m) }\end{array}$ & Metode & $\begin{array}{c}\text { Jumlah } \\
\text { Tiang }\end{array}$ & Harga & $\begin{array}{c}\% \\
\text { Penghematan }\end{array}$ \\
\hline Bor & 1 & 40 & Existing & 35 & Rp. 3.215.800.000 & 100 \\
\hline \multirow[t]{4}{*}{ Pancang } & 0,5 & 40 & Meyerhoff & 60 & Rp. 1.936.879.980 & 39,7 \\
\hline & & & $\begin{array}{c}\text { Meyerhoff } \\
\text { (Uji SPT) }\end{array}$ & 70 & Rp.2.259.693.310 & 29,7 \\
\hline & & & L.Decourt & 70 & Rp.2.259.693.310 & 29,7 \\
\hline & & & Aplikasi & 46 & Rp.1.484.941.318 & 53,8 \\
\hline \multirow[t]{4}{*}{ Pancang } & 0,5 & 36 & Meyerhoff & 60 & Rp. 1.743.192.000 & 45,7 \\
\hline & & & $\begin{array}{c}\text { Meyerhoff } \\
\text { (Uji SPT) }\end{array}$ & 70 & Rp.2.033.724.000 & 36,7 \\
\hline & & & L.Decourt & 72 & Rp.2.091.830.400 & 34,9 \\
\hline & & & Aplikasi & 50 & Rp. 1.452.660.000 & 54,8 \\
\hline
\end{tabular}

\section{KESIMPULAN DAN SARAN}

\section{Kesimpulan}

Dari hasil analisis dan pembahasan di atas tiang pancang dengan diameter 0,5 m sedalam $36 \mathrm{~m}$ dapat menghemat, sekitar Rp.4.033.950.400 dengan persentase efisiensi sebesar 62,15 \% dengan menimbangkan factor keamanan seperti penurunan tiang kelompok, dan daya dukung. Namun dengan jumlah tiang yang lebih banyak. 


\section{Saran}

Perlu dipertimbangkan aspek waktu pelaksanaan untuk fondasi tiang pancang dan tiang bor, dan melihat daya dukung lateral sehingga perlu dikaji lebih jauh.

\section{DAFTAR PUSTAKA}

Bowles, J. E.. Analisis Dan Desain Pondasi. Erlangga, Jakarta. 1989

Das, Braja M, Principles of foundation of Engineering, SI. Seventh Edition, CENGAGE Learning, 2011

Hardiyatmo, Hary Christiandy. “Analisis Dan Perancangan Fondasi.” Analisis Dan Perancangan Fondasi, 2010.

Rahardjo, Paulus P.. Manual Pondasi Tiang. 2005.

Reese, L., and S. Wright. Drilled Shaft Design and Construction Guidelines Manual. 1st ed., U.S Department of Transportation, 1977. 

